DOI: 10.20472/EFC.2017.007.001

\author{
HANA FLORIANOVÁ \\ Masaryk University, Czech Republic
}

\title{
THE PORTFOLIO SELECTION FOR A HEDGING STRATEGY
}

\begin{abstract}
:
Every trader or investor who holds financial instruments has different approach to a portfolio selection. In this paper we focus on a delta-gamma-hedging strategy using an alternative protective collar strategy for shares and warrants approach. We compose a portfolio constiting of shares and warrants. We choose them based on four criteria - liquidity, volatility, correlation and amount. We get nine shares which meet our criteria and warrants which have these shares as underlying assets, the tenth instrument is gold and warrant on gold, representing defensive asset. We make portfolios delta-gamma-neutral and follow their performance in one month period starting in October 2016. The hypothesis stated is that for decreasing shares our strategy will generate above-average profit. In the observed period our strategy resulted in $1.21 \%$ profit, while benchmark was $-0.7 \%$ in loss. That makes approximately $14 \%$ profit per year, even though only seven shares were decreasing while the others were increasing in the observed period. We consider this strategy to be successful. However, it is suitable for bearish trend on capital markets and we ommited taxes and spreads.
\end{abstract}

\section{Keywords:}

portfolio, warrant, strategy, bearish trend 


\section{Introduction}

Every trader or investor who holds financial instruments has different approach to a portfolio selection. We try to find a process of portfolio selection which is independent on investor's current mood and is not affected by his/her psychical conditions. Our method is based on modern portfolio theory introduced by Markowitz (1952). Accordingly to his work the portfolio selection has two stages. First is observation, second is selection. Assume investor is rational and his/her main aim is to maximize profits and he/she prefers lower to higher risk. Therefore, a portfolio is selected based on not only return but risk as well. It is also important to divesify the portfolio by using more assets based on their returns and risk. Presumptions of Markowitz theory are: investor is rational, risk-averse and maximizes returns, it is possible to buy a fraction of an asset, investors accept the price and cannot influence it, there are no taxes and transaction costs, investors make decision based on mean and standard deviation of portfolio returns.

\section{Methodology}

The financial instruments used in our portfolio are warrants and shares. They are chosen in four steps depending on the following criteria - liquidity, volatility, correlation and amount. The dataset was gathered from Frankfurt Stock Exchange from October to November 2016.

\section{Liquidity}

If we want to minimize risk related to the underlying assets, we should choose the most liquid shares. Our research is done on the Frankfurt Stock Exchange therefore we use shares involved in DAX index. It is composed of 30 shares from different fields of economy, e.g. banking, construction, chemistry or health care.

\section{Volatility}

Because our trading strategy is based on delta-gamma-hedging, we choose shares with medium volatility as defined by Florianová (2015). See the volatility of shares in Table 1. The volatility was calculated from daily closing prices in Xetra.

\section{Table 1: Volatility}

\begin{tabular}{|c|c|c|c|c|c|}
\hline Daimler & BMW & Volkswagen & BASF & Beiersdorf & MAN \\
\hline 27.95 & 29.82 & 30.79 & 25.85 & 21.74 & 9.11 \\
\hline $\begin{array}{l}\text { Heidelber- } \\
\text { gcement }\end{array}$ & $\begin{array}{l}\text { Deutsche } \\
\text { Telekom }\end{array}$ & $\begin{array}{c}\text { Deutsche } \\
\text { Bank }\end{array}$ & $\begin{array}{c}\text { Deutsche } \\
\text { Borse }\end{array}$ & $\begin{array}{l}\text { Infineon } \\
\text { Technol. }\end{array}$ & $\begin{array}{c}\text { Deutsche } \\
\text { Post }\end{array}$ \\
\hline 26.68 & 28.1 & 27.82 & 24.62 & 28.61 & 25.85 \\
\hline $\begin{array}{c}\text { Fresenius } \\
\text { SE\&CO }\end{array}$ & $\begin{array}{l}\text { Deutsche } \\
\text { Lufthansa }\end{array}$ & Metro & Adidas & Thyssenkrupp & $\begin{array}{l}\text { Fresenius } \\
\text { MedCare }\end{array}$ \\
\hline 26.18 & 23.21 & 30.34 & 25.3 & 27.37 & 25.89 \\
\hline Linde & Siemens & RWE & Merck & Commerzbank & Bayer \\
\hline 22.32 & 20.61 & 26.2 & 27.3 & 26.1 & 29.87 \\
\hline Munich & SAP & Allianz & Henkel & E.ON & $\mathrm{K}+\mathrm{S}$ \\
\hline 19.25 & 19.52 & 22.72 & 22.05 & 24.29 & 55.6 \\
\hline
\end{tabular}

Source: Author's construction

Companies suitable for a portfolio are Daimler, BMW, Volkswagen, BASF, Heidelbergcement, Commerzbank, Deutsche Bank, Bayer, Fresenius SE\&CO, Merck, Metro, Adidas, Thyssenkrupp, RWE, Deutsche Telekom, Infineon Technologies, 
Fresenius Medical Care a Deutsche Post. Rest of the companies is eliminated from further investigation.

\section{Correlation}

The need to take correlation into account arises from Markowitz's portfolio theory. According to him the assets should not be strongly correlated. Firstly, we find if the data are normally distributed. We find out that some of them are. Although some of them are not normally distributed, we can presume normal distribution thanks to the large dataset. Therefore we use Pearson correlation coefficient. See correlations in table 2.

Table 2: Corellation of call warrants (sample)

\begin{tabular}{|c|c|c|c|c|c|c|c|c|c|}
\hline & Vo. & Co. & Ba. & Fr. & Me. & Ad. & Th. & De. & In. \\
\hline Volkswagen & 1 & 0.42 & 0.39 & 0.65 & 0.77 & -0.57 & -0.31 & -0.32 & -0.64 \\
\hline Commerzbank & 0.42 & 1 & 0.64 & 0.66 & 0.65 & -0.76 & -0.06 & 0.3 & -0.41 \\
\hline Bayer & 0.39 & 0.64 & 1 & 0.67 & 0.43 & -0.73 & 0.26 & 0.4 & -0.15 \\
\hline $\begin{array}{c}\text { Fresenius } \\
\text { Medical Care }\end{array}$ & 0.65 & 0.66 & 0.67 & 1 & 0.81 & -0.75 & -0.29 & 0.29 & -0.36 \\
\hline Metro & 0.77 & 0.65 & 0.43 & 0.81 & 1 & -0.73 & -0.47 & -0.07 & -0.72 \\
\hline Adidas & -0.57 & -0.76 & -0.73 & -0.75 & -0.73 & 1 & 0.02 & -0.3 & 0.5 \\
\hline Thyssenkrupp & -0.31 & -0.06 & 0.26 & -0.29 & -0.47 & 0.02 & 1 & 0.27 & 0.29 \\
\hline $\begin{array}{l}\text { Deutsche } \\
\text { Telekom }\end{array}$ & -0.32 & 0.3 & 0.4 & 0.29 & -0.07 & -0.3 & 0.27 & 1 & 0.31 \\
\hline $\begin{array}{c}\text { Infeon } \\
\text { Technologies }\end{array}$ & -0.64 & -0.41 & -0.15 & -0.36 & -0.72 & 0.5 & 0.29 & 0.31 & 1 \\
\hline
\end{tabular}

Source: Author's construction using software Gretl and the Bloomberg terminal

\section{Amount}

According to Gup a portfolio may reach only the lowest level of risk and cannot go under it even if we add more assets to the portfolio. He states that the distinction in risk between e.g. 10 and 200 shares is irrelevant. Therefore we presume that 10 assets is enough for our portfolio.

\section{Selected companies}

We choose 9 companies from the set of 18 which resulted from the volatility criterion according to their correlation. We also take into account the field of work to eliminate sector risk. We get Volkswagen, Commerzbank, Bayer, Fresenius Medical Care, Metro, Adidas, Thyssenkrupp, Deutsche Telekom and Infineon Technologies.

Finally we add gold as a defensive asset to the portfolio. The weight of every warrant in portfolio is the same, $10 \%$.

\section{Selection of portfolio}

From the long term perspective share markets grow. Our strategy is suitable for declining shares therefore the time horizon needs to be short. We investigate period of 
30 days originated on $28^{\text {th }}$ October 2016 . The characteristics of selected warrants are presented in table 3.

Table 3: Characteristics of call warrants

\begin{tabular}{|l|c|c|c|c|c|c|c|c|c|c|c|}
\hline $\begin{array}{c}\text { Underlying } \\
\text { asset }\end{array}$ & WKN & strike & $\sigma_{0}$ & $\sigma_{\mathbf{t}}$ & $\mathbf{W}_{\mathbf{0}}$ & $\mathbf{W}_{\mathbf{t}}$ & $\Delta_{\mathbf{0}}$ & $\Delta_{\mathrm{t}}$ & $\Gamma_{0}$ & $\Gamma_{\mathrm{t}}$ & $\mathrm{T}$ \\
\hline Volkswagen & CW5H3L & 100 & 0.36 & 0.37 & 2.76 & 2.41 & 0.88 & 0.87 & 0.01 & 0.01 & $13 / 3$ \\
\hline Commerzbank & UT1D1L & 11.5 & 0.7 & 1.47 & 0.001 & 0.001 & 0.7 & 0.03 & 0.07 & 0.04 & $12 / 12$ \\
\hline Bayer & PS9ZHX & 105 & 0.16 & 0.47 & 0.002 & 0.001 & 0.01 & 0.06 & 0.12 & 0.01 & $16 / 12$ \\
\hline Fresenius & UT483T & 104 & 0.33 & 0.92 & 0.001 & 0.001 & 0.01 & 0.03 & 0.24 & 0.01 & $12 / 12$ \\
\hline Metro & PS584P & 22 & 0.37 & 0.90 & 0.54 & 0.59 & 0.95 & 0.9 & 0.09 & 0.03 & $16 / 12$ \\
\hline Adidas & CR1TC9 & 90 & 0.20 & 0.67 & 5.87 & 4.84 & 1 & 1 & 0.32 & 0 & $14 / 12$ \\
\hline Thyssenkrupp & DG33GR & 35 & 0.70 & 1.36 & 0.006 & 0.006 & 0.03 & 0.06 & 0.04 & 0.02 & $16 / 12$ \\
\hline Telekom & HY6SJ7 & 11 & 0.48 & 0.91 & 3.92 & 3.79 & 0.97 & 0.95 & 0.02 & 0.04 & $14 / 12$ \\
\hline Infineon Tech. & CR1TRT & 12.2 & 0.35 & 0.48 & 3.91 & 3.78 & 0.99 & 1 & 0.03 & 0.01 & $14 / 12$ \\
\hline gold & VS24X5 & 1200 & 0.1 & 0.15 & 7.28 & 0.96 & 0.9 & 0.4 & 0.06 & 0.01 & $16 / 12$ \\
\hline
\end{tabular}

Source: Author's construction based on Frankfurt Stock Exchange data

Table 4: Characteristics of put warrants

\begin{tabular}{|l|c|c|c|c|c|c|c|c|c|c|c|}
\hline $\begin{array}{c}\text { Underlying } \\
\text { asset }\end{array}$ & WKN & strike & $\sigma_{0}$ & $\sigma_{\mathrm{t}}$ & $\mathrm{W}_{0}$ & $\mathrm{~W}_{\mathrm{t}}$ & $\boldsymbol{\Delta}_{\mathbf{0}}$ & $\boldsymbol{\Delta}_{\mathrm{t}}$ & $\Gamma_{0}$ & $\Gamma_{\mathrm{t}}$ & $\mathrm{T}$ \\
\hline Volkswagen & TD6567 & 140 & 0.38 & 0.49 & 1.56 & 1.78 & -0.88 & -0.89 & 0.01 & 0.01 & $14 / 12$ \\
\hline Commerzbank & GL57Z7 & 8.5 & 0.68 & 0.41 & 3.16 & 3.05 & -0.5 & -0.57 & 0.08 & 0.09 & $21 / 12$ \\
\hline Bayer & CX4WQV & 100 & 0.34 & 0.24 & 1.08 & 1.16 & -0.76 & -0.84 & 0.01 & 0.02 & $13 / 2$ \\
\hline Fresenius & PB8XWM & 95 & 0.31 & 0.31 & 2.04 & 2.11 & -0.89 & -0.95 & 0.01 & 0.01 & $17 / 2$ \\
\hline Metro & CR5SD8 & 18 & 0.10 & 1.10 & 0.001 & 0.001 & -0.01 & -0.02 & 0.01 & 0.01 & $14 / 12$ \\
\hline Adidas & PB5044 & 112 & 0.37 & 0.28 & 0.1 & 0.063 & -0.07 & -0.05 & 0.04 & 0.01 & $17 / 2$ \\
\hline Thyssenkrupp & CX4ZVX & 21.5 & 0.33 & 0.31 & 1.59 & 1.18 & -0.53 & -0.55 & 0.12 & 0.17 & $16 / 1$ \\
\hline Telekom & GD0X8T & 15.6 & 0.21 & 0.21 & 1.02 & 0.96 & -0.66 & -0.74 & 0.40 & 0.27 & $20 / 1$ \\
\hline Infineon Tech. & PB8XME & 17 & 0.37 & 0.32 & 1.51 & 1.3 & -0.55 & -0.64 & 0.22 & 0.19 & $20 / 1$ \\
\hline gold & VN4LVY & 1150 & 0.18 & 0.17 & 0.25 & 0.99 & -0.06 & -0.26 & 0.01 & 0.01 & $6 / 1$ \\
\hline
\end{tabular}

Source: Author's construction based on Frankfurt Stock Exchange data

In table 5 the prices of shares and gold are available.

Table 5: Prices of underlying assets (in EUR) 


\begin{tabular}{|l|c|c|}
\hline \multicolumn{1}{|c|}{ Asset } & So $_{0 \mid}$ & St \\
\hline Volkswagen & 125.35 & 122.599 \\
\hline Commerzbank & 6.27 & 6.445 \\
\hline Bayer & 90.572 & 88.8 \\
\hline Fresenius Medical Care & 74.586 & 73.68 \\
\hline Metro & 27.272 & 27.755 \\
\hline Adidas & 149.252 & 138.967 \\
\hline Thyssenkrupp & 20.931 & 21.118 \\
\hline Deutsche Telekom & 14.848 & 14.779 \\
\hline Infineon Tech. & 16.241 & 16.069 \\
\hline gold & 1284.25 & 1194.75 \\
\hline
\end{tabular}

Source: Author's construction based on Frankfurt Stock Exchange data

\section{Delta-gamma-neutral portfolio}

Our portfolio is delta-gamma-neutral and we apply alternative protective collar strategy (strikes of puts and calls are switched). Meaning that we use certain amount of shares and put warrants and call warrants on these shares. We use Black-Scholes model as presented by Black and Scholes (1973). Delta and gamma are characteristics of warrants and they can be derived from Black-Scholes model through partial derivation (Hull, 2012). The initial position of portfolio is 1000 underlying assets and 1000 call warrants. For an example see table 6.

Table 6: An example ofportfolio-Volkswagen (in EUR)

\begin{tabular}{|c|c|c|c|c|c|c|c|c|}
\hline & \multicolumn{2}{|c|}{ initial } & \multicolumn{2}{|c|}{ gamma-neutral } & \multicolumn{2}{|c|}{ delta-neutral } & \multirow{2}{*}{\begin{tabular}{|c|} 
present \\
value
\end{tabular}} & \multirow{2}{*}{\begin{tabular}{|l|} 
profit \\
value
\end{tabular}} \\
\hline asset & amount & value & amount & value & amount & value & & \\
\hline call warrant & 1000 & 2760 & 1000 & 2760 & 1000 & 890 & 2410 & 1520 \\
\hline put warrant & 0 & 0 & -481 & -1182 & -481 & -976 & $-856,18$ & 119,82 \\
\hline share & 1000 & 125350 & 1000 & 125350 & -1297 & -162631 & $\mid-15902$ & 3569 \\
\hline
\end{tabular}

Source: Author's construction using Excel software

Call warrants on Volkswagen shares in long position make a profit of 1520 EUR in the given period, put warrants in short position make a profit of 119.82 EUR andshares in short position make a profit of 3569 EUR. The total profit was 5209 EUR. Rate of return for the given period is $4.06 \%$. The annual rate of return is approximately $48.8 \%$.

The summary of results calculated for all the companies are listed in table 7 . 
Table 7: Profits and losses of portfolios (in EUR)

\begin{tabular}{|l|c|c|c|c|c|}
\hline \multicolumn{1}{|c|}{ asset } & Profit call & Profit put & Profit underlying & Total profit & Profit in \% \\
\hline Volkswagen & 1520 & 119.82 & 3569 & 5209 & 4.06 \\
\hline Commerzbank & -889 & 274.85 & -143 & -757 & -12 \\
\hline Bayer & -889 & -12944 & 16178 & 2345 & 2.58 \\
\hline Fresenius & -889 & -1680 & 19361 & 16792 & 22 \\
\hline Metro & -300 & 0 & -502 & -802 & -2.89 \\
\hline Adidas & 3950 & 296 & 16045 & 20291 & 0.13 \\
\hline thyssenkrupp & -884 & 136.667 & -39 & -786 & -0.03 \\
\hline Telekom & 2900 & 3 & 69 & 2972 & 0.15 \\
\hline Infineon tech. & 2890 & 28.64 & 183 & 3102 & 0.15 \\
\hline gold & 70 & -4440 & 112770 & 108400 & 0.08 \\
\hline
\end{tabular}

Source: Author's construction using Excel software

\section{A comparison of our portfolio and benchmark}

To evaluate the success of our strategy, it must be compared with benchmark. In our case, we take DAX index as benchmark as we use shares involved in this index. See performance of DAX in a corresponding time period in figure 1.

Figure 1: The performace of DAX from 28/10/2016 to 29/11/2016 (in points)

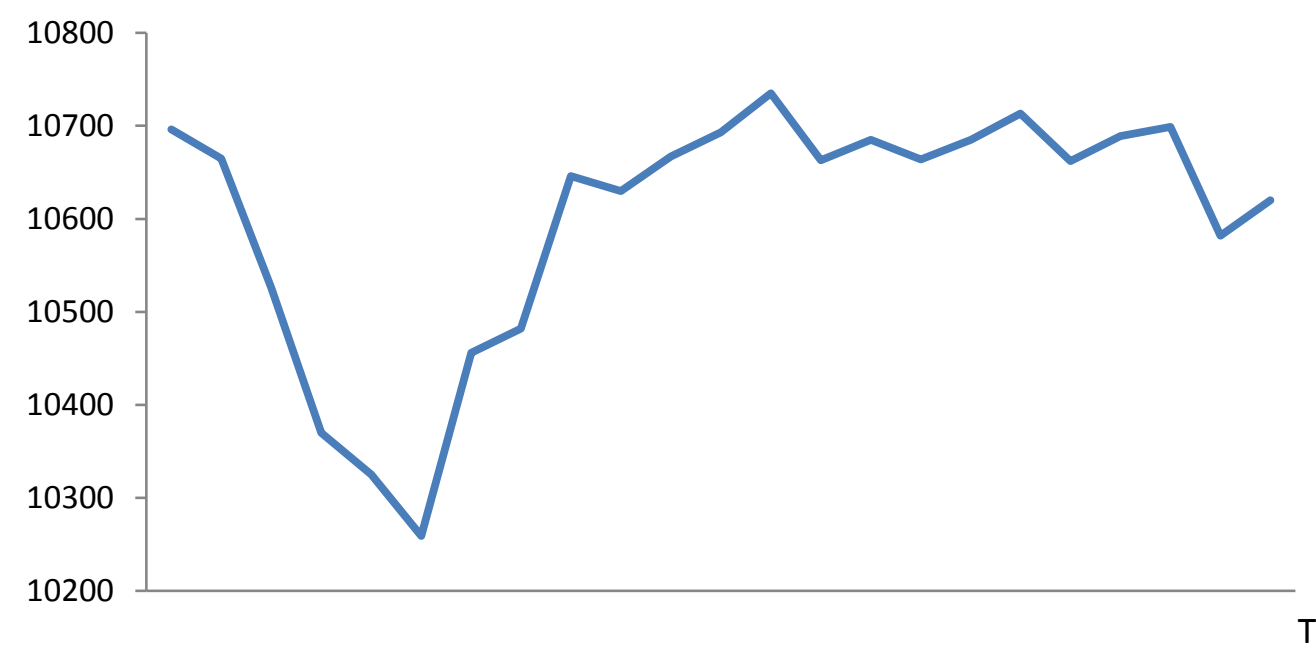

Source: Author's construction based on Bloomberg data using Excel software 
Figure 2: The performace of DAX from 29/11/2015 to 29/11/2016 (in points)

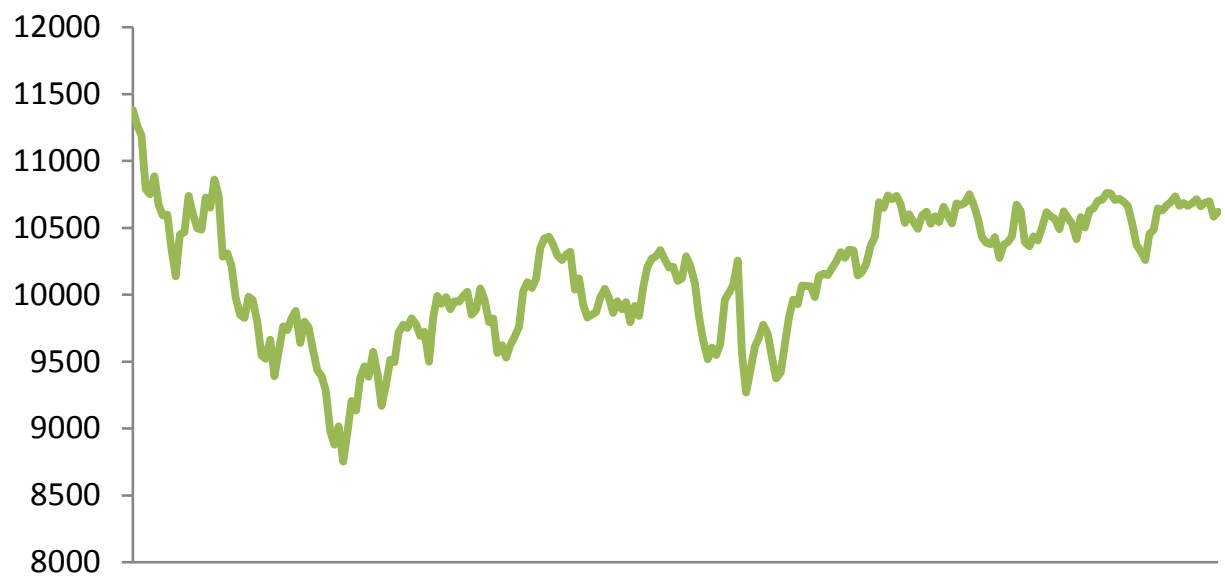

Source: Author's construction based on Bloomberg data using Excel software

The closing value of DAX to date of portfolio origin (28/10/2016) was 10696.19 . The closing value of DAX to date of portfolio exercise (29/11/2016) was 10620.49. The closing value of DAX to annual date $(30 / 11 / 2015)$ was 11382.23 . There was a declension of $0.7 \%$ in our investment horizon and $6.7 \%$ per year. See comparison in table 8.

Table 8: The performace of our strategy and benchmark

\begin{tabular}{|c|c|c|}
\cline { 2 - 3 } \multicolumn{1}{c|}{} & Benchmark (DAX) & Portfolio \\
\hline Investment horizon (one month) & $-0.7 \%$ & $1.21 \%$ \\
\hline Annual & $-6.7 \%$ & $14.5 \%$ \\
\hline
\end{tabular}

Source: Author's construction

\section{Conslusion}

Our strategy of portfolio selection based on alternative collar strategy and delta-gammahedging has proven to be successful. Our portfolio beated the benchmark even though only seven out of ten chosen underlying assets were declining in the given period of time and our strategy is intended for declining assets. If we managed to choose more suitable shares, the strategy could be even more successful. However, the results are influenced by omitting spreads, taxes and dividends.

\section{Acknowledgement}

Support of Masaryk University within the project MUNI/A/0823/2016 "Behavioral, knowledge and economic aspects of pricing and trading in financial and other assets" is gratefully acknowledged.

\section{References}

BLACK, F. and SCHOLES, M. (1973).The Pricing of Options and Corporate Liabilities. Journal of Political Economy. 1973, Vol. 81, No. 3, pp. 637-654.

FLORIANOVÁ, H. (2015). Influence of Volatility on Hedging Strategies. Proceedings of the 12th International Scientific Conference European Financial Systems. Brno: Masaryk University. 2015, pp. 129-134.

GUP, B. E. (1992). The basics of investing. 5th ed. New York: J. Wiley..

HULL, J. (2012).Options, futures, and other derivatives, 8th ed. Boston: Pearson. 
MARKOWITZ, H. (1952). Portfolio selection. Journal of Finance. 1952, Vol. 7, No. 1, pp. 77-91. 